\title{
DIAGRID STRUCTURAL SYSTEM: STRATEGIES TO REDUCE LATERAL FORCES ON HIGH-RISE BUILDINGS
}

\author{
Nishith B. Panchal ${ }^{1}$, Vinubhai R. Patel ${ }^{2}$ \\ ${ }^{I} P G$ student, Applied Mechanics \& Structural Engineering Department, Faculty of Technology \& Engineering, The M. S. \\ University of Baroda, Vadodara, Gujarat, India \\ ${ }^{2}$ Assistant Professor, Applied Mechanics \& Structural Engineering Department, Faculty of Technology \& Engineering, \\ The M. S. University of Baroda, Vadodara, Gujarat, India
}

\begin{abstract}
The evolution of tall building structural systems based on new structural concepts with newly adopted high strength materials and construction methods have been towards "stiffness" and "lightness". Structural systems are become "lighter" and "stiffer". It is common knowledge that rather than directly standing the forces, it is better to reduce them and dissipate the magnitude of vibrations. Structure design of high rise buildings is governed by lateral loads due to wind or earthquake. Lateral load resistance of structure is provided by interior structural system or exterior structural system. The selected structural system should be such that it should be effectively utilized for structural requirements. Recently diagrid structural system is adopted in tall buildings due to its structural efficiency and flexibility in architectural planning. Diagrid structure consists of inclined columns on the exterior surface of buildings compared to closely space vertical columns in framed tubes. The lateral loads are resisted by axial action of the diagonal. In this paper, the comparison study of 20-storey simple frame building and diagrid structural system building is presented here. The comparison of analysis of results in terms of top storey displacement, storey drift, steel and concrete consumption is presented here.
\end{abstract}

Keywords: Diagrid Structural System, High-Rise Building, Storey Drift and Top-Storey Displacement

\section{INTRODUCTION}

The rapid growth of urban population and limitation of available land, the taller structures are preferable now a day. So when the height of structure increases then the consideration of lateral load is very much important. For that the lateral load resisting system becomes more important than the structural system that resists the gravitational loads. The lateral load resisting systems that are widely used are rigid frame, shear wall, wall frame, braced tube system, outrigger system and tubular system. Recently the diagrid - diagonal grid structural system is widely used for tall buildings due to its structural efficiency and aesthetic potential provided by the unique geometric configuration of the system. Hence the diagrid, for structural effectiveness and aesthetics has generated renewed interest from architectural and structural designers of tall buildings.

The difference between conventional exterior-braced frame structures and current diagrid structures is that, for diagrid structures, almost all the conventional vertical columns are eliminated. This is possible because the diagonal members in diagrid structural systems can carry gravity loads as well as lateral forces owing to their triangulated configuration, whereas the diagonals in conventional braced frame structures carry only lateral loads. Compared with conventional framed tubular structures without diagonals, diagrid structures are much more effective in minimizing shear deformation because they carry shear by axial action of the diagonal members, while conventional framed tubular structures carry shear by the bending of the vertical columns. Diagrid structures do not need high shear rigidity cores because shear can be carried by the diagrids located on the perimeter.

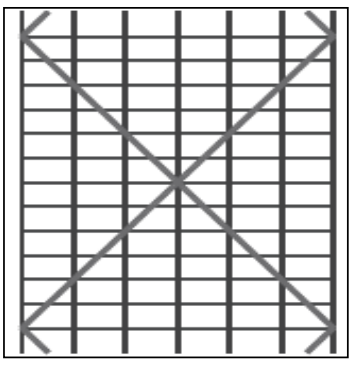

(i)

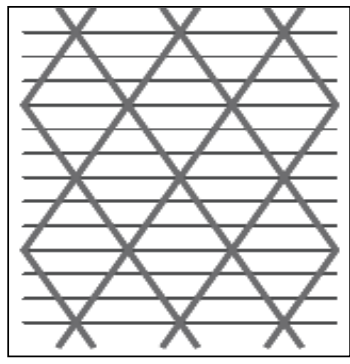

(ii)
Fig-1: (i) Braced Tube, (ii) Diagrid Structure

Diagrid has good appearance and it is easily recognized. The configuration and efficiency of a diagrid system reduce the number of structural element required on the façade of the buildings, therefore less obstruction to the outside view. The structural efficiency of diagrid system also helps in avoiding interior and corner columns, therefore allowing significant 
flexibility with the floor plan. Perimeter "diagrid" system saves approximately 20 percent structural steel weight when compared to a conventional moment-frame structure.

An early example of the diagrid structure is the IBM Building in Pittsburgh built in the early 1960s, with its 13-storey building height. Another famous examples of diagrid structure all around the world are the Swiss Re London, Hearst Tower in New York, Capital Gate tower in Abu Dhabi, Cyclone Tower in Asan (Korea) and new World Trade Centre in New York.

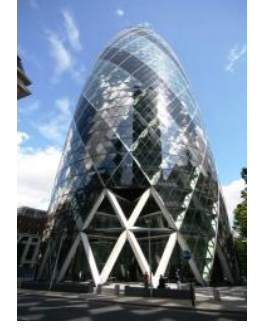

(i)

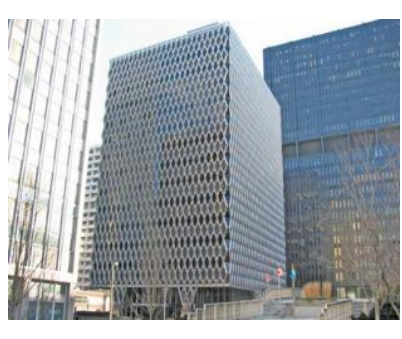

(ii)

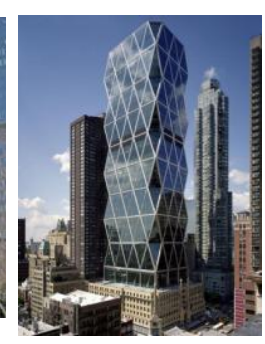

(iii)
Fig- 2: (i) Swiss Re London, (ii) IBM Building, (iii) Hearst Tower

In this paper, a comparative study of 20-storey simple frame building and with same configuration, a diagrid structural system building is presented here. A simple floor plan of $18 \mathrm{~m}$ x $18 \mathrm{~m}$ size is considered. ETABS 9.7.4 software is used for modelling and analysis of structural members. The analysis is carried out for 20 -storey building with floor height $3.6 \mathrm{~m}$. Comparison of analysis results in terms of top storey displacement, inter storey drift, storey shear, steel and concrete consumption is presented here.

\section{ANALYSIS OF 20-STOREY BUILDING}

\subsection{Building Configuration}

The 20 -storey building is having $18 \mathrm{~m} \times 18 \mathrm{~m}$ plan dimension and $72 \mathrm{~m}$ total height of building. The storey height is $3.6 \mathrm{~m}$. The typical plan and elevation are shown in figure 3 . There are two models for comparative study, one is for simple frame building and another is for diagrid structure. The building data is kept same for both models. The beam size and column sizes are as shown in table-1. The slab thickness is $120 \mathrm{~mm}$. The diagonal member's (Diagrid) size is $300 \mathrm{~mm} \times 300 \mathrm{~mm}$ for diagrid structure and it is at the angle of $78.2^{\circ}$. And for simple frame building, the perimeter columns sizes are also $450 \mathrm{~mm} \mathrm{x}$ $450 \mathrm{~mm}$. The design dead load and live load on terrace level are $5.6 \mathrm{kN} / \mathrm{m} 2$ and $1.5 \mathrm{kN} / \mathrm{m} 2$ respectively and for typical floor slab is $4.6 \mathrm{kN} / \mathrm{m} 2$ and $2 \mathrm{kN} / \mathrm{m} 2$. The design earthquake load is computed based on the zone factor 0.16 , soil type II, Importance factor 1, Response Reduction 5 as per IS-18932002. The design wind load is computed based on location Vadodara, Wind speed $44 \mathrm{~m} / \mathrm{s}$, Terrain category 2, Structure class B, Risk Coefficient 1, Topography factor 1. Modelling, analysis and design of diagrid structure are carried out using ETABS 9.7.4 software. The end condition for diagrid is assumed as hinged. The support conditions are assumed as fixed. The design of member is carried out on the basis of IS456-2000.

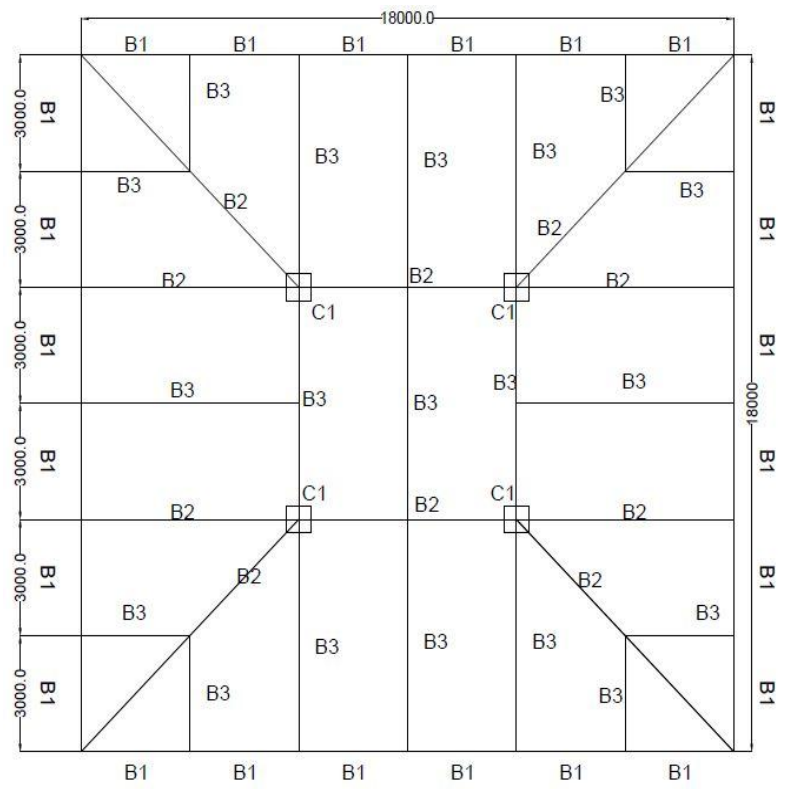

(i)

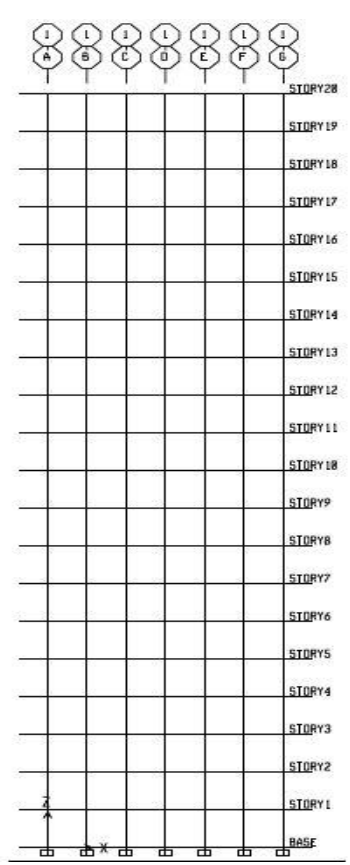

(ii)

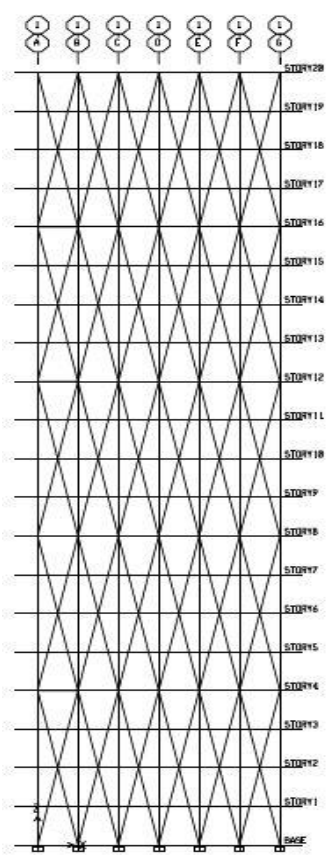

(iii)
Fig- 3: (i) plan (ii) elevation of simple frame structure, (iii) elevation of diagrid structure 


\subsection{Analysis Results}

The analysis results in terms of displacement, inter storey drift, storey shear are presented here. The summary reaction of Gravity loads, lateral loads due to earthquake and wind is shown in table-2.

Table: - 1 Reaction

\begin{tabular}{|l|l|l|}
\hline LOADING (KN) & $\begin{array}{l}\text { TOTAL } \\
\text { REACTION } \\
\text { ON DIAGRID } \\
\text { STRUCTURE }\end{array}$ & $\begin{array}{l}\text { TOTAL } \\
\text { REACTION } \\
\text { ON SIMPLE } \\
\text { FRAME } \\
\text { STRUCTURE }\end{array}$ \\
\hline $\begin{array}{l}\text { GRAVITY } \\
\text { LOAD(DL + LL) }\end{array}$ & 84144.02 & 87600.17 \\
\hline $\begin{array}{l}\text { EQ LOAD IN X- } \\
\text { DIR }\end{array}$ & 905.13 & 931.07 \\
\hline $\begin{array}{l}\text { EQ LOAD IN Y- } \\
\text { DIR }\end{array}$ & 905.13 & 931.07 \\
\hline $\begin{array}{l}\text { WIND LOAD IN X- } \\
\text { DIR }\end{array}$ & 2310.11 & 2310.11 \\
\hline $\begin{array}{l}\text { WIND LOAD IN Y- } \\
\text { DIR }\end{array}$ & 2310.11 & 2310.11 \\
\hline
\end{tabular}

The displacement of 20-storey diagrid structure and simple frame structure building is shown in fig- 4 . It is observed that displacement in simple frame is higher compared to the diagrid frame building in EQX, EQY, WLX and WLX case. The inter storey drift of diagrid structure and simple frame structure building is shown in fig-5. It is observed that inter storey drift in simple frame building is higher compared to the diagrid frame building EQX, EQY, WLX and WLX case. The distribution of storey shear along the height of 20-storey diagrid building and simple frame building is shown in fig-6. It is observed that storey shear in simple frame building is higher compared to the diagrid frame building EQX, EQY, WLX and WLX case. All the results are as shown in table-2.

Table:-2 Displacement Results

\begin{tabular}{|c|c|c|c|c|}
\hline & CASE & $\begin{array}{l}\text { DIAGRID } \\
\text { STRUCT } \\
\text { URE }\end{array}$ & $\begin{array}{l}\text { SIMPLE } \\
\text { FRAME } \\
\text { BUILDI } \\
\text { NG }\end{array}$ & $\begin{array}{l}\text { PERMI } \\
\text { SSIBLE } \\
\text { VALU } \\
\text { ES }\end{array}$ \\
\hline \multirow{2}{*}{$\begin{array}{l}\text { TOP } \\
\text { STOREY } \\
\text { DISPLAC } \\
\text { EMENT }\end{array}$} & $\begin{array}{l}\text { EQX/EQ } \\
Y\end{array}$ & $31.5 \mathrm{~mm}$ & $78.3 \mathrm{~mm}$ & $144 \mathrm{~mm}$ \\
\hline & $\begin{array}{l}\text { WLX/WL } \\
Y\end{array}$ & $53.9 \mathrm{~mm}$ & $132.3 \mathrm{~mm}$ & $144 \mathrm{~mm}$ \\
\hline \multirow[t]{2}{*}{$\begin{array}{l}\text { STOREY } \\
\text { DRIFT }\end{array}$} & $\begin{array}{l}\text { EQX/EQ } \\
Y\end{array}$ & $0.264 \mathrm{~mm}$ & $0.483 \mathrm{~mm}$ & $14.4 \mathrm{~mm}$ \\
\hline & $\begin{array}{l}\text { WLX/WL } \\
Y\end{array}$ & $0.353 \mathrm{~mm}$ & $0.542 \mathrm{~mm}$ & $14.4 \mathrm{~mm}$ \\
\hline
\end{tabular}




\section{DESIGN OF 20-STOREY DIAGRID AND SIMPLE FRAME BUILDING}

The design of diagrid structure and simple frame building is carried out using ETABS 9.7.4 software. The gravity load, earth quake load and wind load are assigned to both structure with all load combinations. From the analysis results design of beam, column and diagonal members is carried out as per IS: 456-2000. The compressive strength of concrete is $40 \mathrm{~N} / \mathrm{mm} 2$ and for steel $415 \mathrm{~N} / \mathrm{mm} 2$ is considered. The beam and column sizes are preliminary decided for both the building. Then after analysis the sizes are changed to prevent the failure and excessive top storey displacement. So the final sizes of members optimum sizes for both the buildings as shown in table-3.

Table:-3 Member sizes for both models

\begin{tabular}{|l|l|l|l|}
\hline MEMBER & $\begin{array}{l}\text { MEMBER } \\
\text { NOS. }\end{array}$ & $\begin{array}{l}\text { DIAGRID } \\
\text { STRUCTURE }\end{array}$ & $\begin{array}{l}\text { SIMPLE } \\
\text { FRAME } \\
\text { STRUCTURE }\end{array}$ \\
\hline BEAM & B1 & $\begin{array}{l}230 \mathrm{~mm} \times 500 \\
\mathrm{~mm}\end{array}$ & $\begin{array}{l}300 \mathrm{~mm} \times 600 \\
\mathrm{~mm}\end{array}$ \\
\hline & $\mathrm{B} 2$ & $\begin{array}{l}230 \mathrm{~mm} \times 500 \\
\mathrm{~mm}\end{array}$ & $\begin{array}{l}230 \mathrm{~mm} \times 500 \\
\mathrm{~mm}\end{array}$ \\
& $\mathrm{~B} 3$ & $\begin{array}{l}230 \mathrm{~mm} \times 450 \\
\mathrm{~mm}\end{array}$ & $\begin{array}{l}230 \mathrm{~mm} \times 450 \\
\mathrm{~mm}\end{array}$ \\
\hline COLUMN & $\mathrm{C} 1$ & $\begin{array}{l}700 \mathrm{~mm} \times 700 \\
\mathrm{~mm}\end{array}$ & $\begin{array}{l}750 \mathrm{~mm} \times 750 \\
\mathrm{~mm}\end{array}$ \\
\hline DIAGRID & $\mathrm{D} 1$ & $\begin{array}{l}300 \mathrm{~mm} \times 300 \\
\mathrm{~mm}\end{array}$ & $\begin{array}{l}450 \mathrm{~mm} \times 450 \\
\mathrm{~mm}\end{array}$ \\
\hline
\end{tabular}

\subsection{Material Consumption}

The consumption of concrete and steel is calculated for both the building. It is observed that the consumption of material for simple frame building is higher than the diagrid structure building. The difference in the consumption of concrete for both the building is $13.01 \%$ and for steel is $57.9 \%$ which is shown in the figure-6.

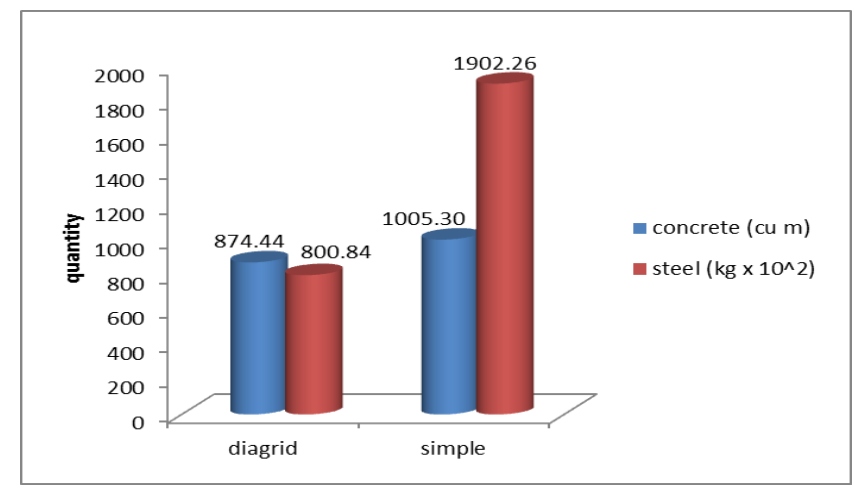

Fig - 7 Quantity of Diagrid Structure and simple frame structure

\section{CONCLUSIONS}

In this paper, comparative analysis and design of 20-storey diagrid structural system building and simple frame building is presented here. A regular floor plan of $18 \mathrm{~m} \times 18 \mathrm{~m}$ size is considered. ETABS 9.7.4 software is used for modelling and analysis of structure. Analysis results like displacement, storey drift, storey shear are presented here. Also design of both structures is done and optimum member sizes are decided to satisfy the code criteria.

We conclude from the study that,

$>$ As the lateral loads are resisted by diagonal columns, the top storey displacement is very much less in diagrid structure as compared to the simple frame building.

$>$ The storey drift and storey shear is very much less for diagrid structural system.

$>$ Diagrid provide more resistance in the building which makes system more effective.

$>$ The design of both structures are done by using same member size but that member sizes are not satisfied to design criteria in case of simple frame structure and failure occurs with excessive top storey displacement. So the higher sizes of members are selected to prevent the failure criteria.

$>$ Diagrid structure system provides more economy in terms of consumption of steel and concrete as compared to simple frame building.

$>$ Diagrid structural system provides more flexibility in planning interior space and façade of the building.

\section{ACKNOWLEDGEMENTS}

I am very much thankful to my guide Dr. Vinubhai R. Patel for their guidance and also very much thankful to Applied Mechanics Department \& Structural Engineering Department, Faculty of Technology \& Engineering, The M. S. University Of Baroda for giving such a good facilities and platform to complete the dissertation work and also my dear friends who have support me to complete this work.

\section{REFERENCES}

[1]. Kyoung S. Moon, Jerome J. Connor and John E. Fernandez, "Diagrid Structural Systems for Tall Building: Characteristics and Methodology For Preliminary Design", Willey Interscience Publication.

[2]. Khushbu Jani and Paresh V. Patel, "Analysis and Design of Diagrid Structural System for High Rise Steel Buildings", Published by Elesevier Ltd.

[3]. Mir M. Ali and Kyoung S. Moon, "Structural Developments in Tall Buildings: Current Trends and Future Prospects", Architectural Science Review Vol 50.3, pp 205223.

[4]. Kyoung S. Moon, "Diagrid Structures for ComplexShaped Tall Building", Published by Elesevier Ltd. 
[5]. J. Kim, Y.Jun and Y.-Ho Lee, "Seismic Performance Evaluation of Diagrid System Buildings", 2nd Specially Conference on Disaster Mitigation, Manitoba.

[6]. Charnish B. and McDonnell T. "The Bow: Unique Diagrid Structural System for a Sustainable Tall Building", CTBUH 8th World Congress, Dubai.

[7]. IS: 456-2000. Plain and Reinforced Concrete- Code of Practice (Fourth Revision), Bureau of Indian Standard, New Delhi.

[8]. IS: 1893(Part-I)-2002, Criteria for Earthquake Resistant Design of Structures, Bureau of Indian Standard, New Delhi.

[9]. IS: 875(Part-I, II, III)-1987, Code of Practice for Design Loads (other than Earthquake) for Buildings and Structures, Bureau of Indian Standard, New Delhi.

\section{BIOGRAPHIES}

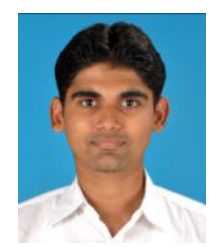

I am Nishith B. Panchal. I am pursuing my Master Of Engineering study in Structural engineering branch from The M. S. University of Baroda. I am doing my dissertation work under the guidance of Dr. V. R. Patel sir. I have done my Bachelor of Engineering (civil engg) study also from The M. S. University of Baroda.

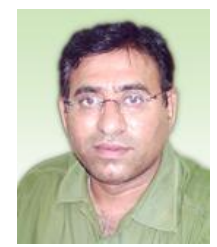

Dr. Vinubhai R. Patel is an Assistant Professor in Applied Mechanics and Structure Engineering Department, Faculty Of Technology \& Engineering, The M. S. University of Baroda. He is also a structure designed consultant and approved valuer. $\mathrm{He}$ has more than 15 years of experience in the field of structural and civil engineering. He had designed more than 1500 projects which includes industrial, factory buildings and highrise buildings. 